Article

\title{
The Role of Natural Laccase Redox Mediators in Simultaneous Dye Decolorization and Power Production in Microbial Fuel Cells
}

\author{
Priyadharshini Mani ${ }^{1, *}$, Vallam Thodi Fidal Kumar ${ }^{2}$, Taj Keshavarz ${ }^{1}$, T. Sainathan Chandra ${ }^{2}$ \\ and Godfrey Kyazze ${ }^{1, *}$ \\ 1 Faculty of Science and Technology, University of Westminster, $115 \mathrm{New}$ Cavendish Street, \\ London W1W 6UW, UK; T.Keshavarz@westminster.ac.uk \\ 2 Department of Biotechnology, Indian Institute of Technology (Madras), Chennai 600036, India; \\ vtfkbt@gmail.com (V.T.F.K.); chandrasainathan@gmail.com (T.S.C.) \\ * Correspondence: Priyadharshini.Mani@my.westminster.ac.uk (P.M.); G.Kyazze@westminster.ac.uk (G.K.)
}

Received: 1 November 2018; Accepted: 8 December 2018; Published: 10 December 2018

Abstract: Redox mediators could be used to improve the efficiency of microbial fuel cells (MFCs) by enhancing electron transfer rates and decreasing charge transfer resistance at electrodes. However, many artificial redox mediators are expensive and/or toxic. In this study, laccase enzyme was employed as a biocathode of MFCs in the presence of two natural redox mediators (syringaldehyde (Syr) and acetosyringone (As)), and for comparison, a commonly-used artificial mediator 2,2'-azinobis(3-ethylbenzthiazoline-6-sulfonic acid) (ABTS) was used to investigate their influence on azo dye decolorization and power production. The redox properties of the mediator-laccase systems were studied by cyclic voltammetry. The presence of ABTS and As increased power density from $54.7 \pm 3.5 \mathrm{~mW} \mathrm{~m}^{-2}$ (control) to $77.2 \pm 4.2 \mathrm{~mW} \mathrm{~m}^{-2}$ and $62.5 \pm 3.7 \mathrm{~mW} \mathrm{~m}^{-2}$ respectively. The power decreased to $23.2 \pm 2.1 \mathrm{~mW} \mathrm{~m}^{-2}$ for laccase with Syr. The cathodic decolorization of Acid orange 7 (AO7) by laccase indicated a 12-16\% increase in decolorization efficiency with addition of mediators; and the Laccase-Acetosyringone system was the fastest, with $94 \%$ of original dye $\left(100 \mathrm{mgL}^{-1}\right)$ decolorized within $24 \mathrm{~h}$. Electrochemical analysis to determine the redox properties of the mediators revealed that syringaldehyde did not produce any redox peaks, inferring that it was oxidized by laccase to other products, making it unavailable as a mediator, while acetosyringone and ABTS revealed two redox couples demonstrating the redox mediator properties of these compounds. Thus, acetosyringone served as an efficient natural redox mediator for laccase, aiding in increasing the rate of dye decolorization and power production in MFCs. Taken together, the results suggest that natural laccase redox mediators could have the potential to improve dye decolorization and power density in microbial fuel cells.

Keywords: acetosyringone; dye decolorization; laccase; natural redox mediators; power density; syringaldehyde

\section{Introduction}

Microbial fuel cells (MFCs) could have potential in treating dyeing effluents with simultaneous power production. At the cathode of MFCs, platinum and metal oxide catalysts are commonly used for the oxygen reduction reaction (ORR). In recent years oxidoreductase enzymes e.g., laccase, have been explored as cathode catalysts in MFCs as a possible alternative to platinum as a way of reducing the cost of materials needed to construct MFCs [1,2]. Laccase is a multi-copper containing enzyme that is capable of one electron oxidation of other substrates and four electron reduction of $\mathrm{O}_{2}$ to $\mathrm{H}_{2} \mathrm{O}[3,4]$. 
The enzyme is widely utilised in the oxidation of phenolic and non-phenolic substrates such as dyes, pesticides, antibiotics etc.

The redox potential of the substrate should be lower than that of laccase for oxidation to be thermodynamically feasible. The redox potential range for fungal laccase is between $0.4-0.8 \mathrm{~V}$ vs. standard hydrogen electrode (SHE), which is suitable for oxidation of phenolic substrates; for non-phenolic substrates that have a redox potential of $>1.3 \mathrm{~V}$ vs. SHE, and cannot be oxidized directly by laccase, a redox mediator is required [5]. A redox mediator is a small molecular weight compound that is oxidized by the enzyme and reduced by the substrate continuously. They act as electron shuttles for large substrates that cannot access the active site of the enzyme, e.g., due to steric hindrance [6]. In laccase mediator systems (LMS), the enzyme oxidizes the mediators to form stable radicals with high redox potential that diffuse away from the enzyme active site and oxidize the substrates and get reduced in the process. In this way, laccase indirectly oxidises substrates that have high redox potentials or large molecular sizes [7] (Figure 1).

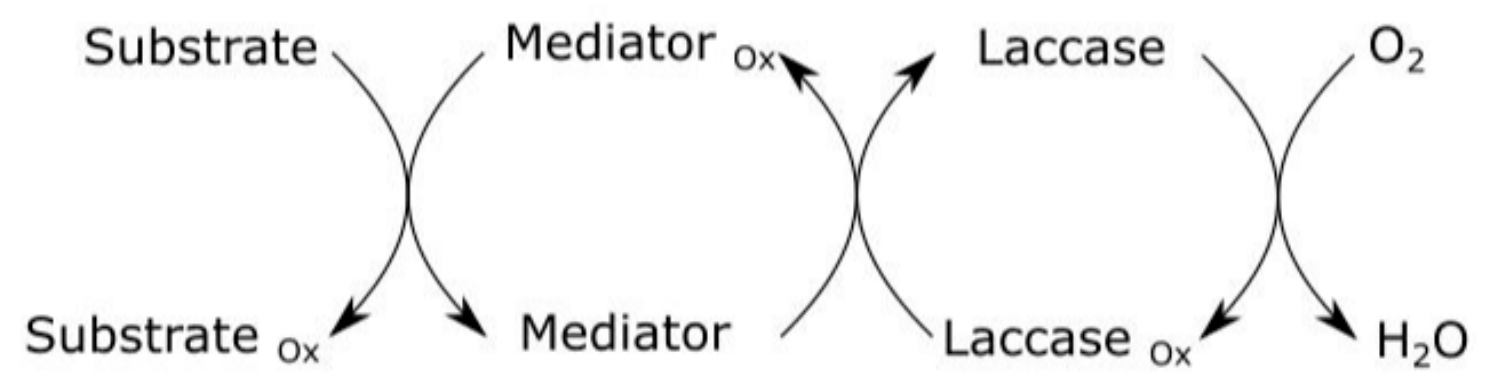

Figure 1. Laccase indirect substrate oxidation through mediators with oxygen as the final electron acceptor (Modified from [5]).

The first synthetic redox mediator reported was 2,2'-azinobis(3-ethylbenzthiazoline-6-sulfonic acid) (ABTS) for laccase from Trametes versicolor for oxidation of non-phenolic lignin compounds [8]. Another mediator that is involved in laccase lignin degradation and bleaching of kraft pulps is 1-Hydroxybenzotriazole (HBT) [9]. The LMS were initially used for delignification and bio-bleaching of wood pulps; nowadays, they are widely used for the degradation of xenobiotic compounds [10-12].

Although ABTS and HBT are the most widely used redox mediators for laccase, artificial mediators are not economically feasible, and they are toxic to the enzymes in the long run. In recent times, natural mediators have been explored for their environmental friendliness and low-cost. These natural mediators are phenolic compounds that exist in nature and mediate lignin oxidation in white rot fungi. Commonly-used phenolic mediators are syringaldehyde, acetosyringone, vanillin, methyl vanillate, $p$-coumaric acid, etc. [11]. The above mediators were compared with ABTS and HBT for the decolorization of different dyes with laccase from T. versicolor and Pycnoporous cinnabarinus. Syringaldehyde and acetosyringone showed $100 \%$ decolorization of Acid blue 74 with both laccases while there was $>85 \%$ decolorization for Reactive Black 5 dye in less than $1 \mathrm{~h}$ for both the dyes. There was less than $50 \%$ decolorization of Acid Blue 74 by ABTS and HBT in the same time period. The phenolic mediators were more rapid and efficient in the oxidation of dyes than their synthetic counterparts [13]. The decolorization efficiency of various LMS depends on the dye structure. The mechanism of laccase mediation varies between each mediator. It was, for example, observed for lignin oxidation that ABTS/Laccase carried out alpha carbon oxidation and coupling of the lignin subunits, whereas HBT/laccase polymerized them [14].

Laccase stability and activity was decreased when incubated with artificial redox mediators ABTS, HBT, TEMPO (2,2,6,6-tetramethylpiperidin-1-yl)oxidanyl), and violuric acid (VA) at a concentration of $0.5 \mathrm{mM}$ [14]. Even in the absence of any mediator, laccase activity decreased from $1000 \mathrm{U} \mathrm{L}^{-1}$ to $290 \mathrm{U} \mathrm{L}^{-1}$ in 15 days [15]. It is probably for this reason that high enzyme loadings such as $500 \mathrm{U} \mathrm{mL}^{-1}$ to $2000 \mathrm{U} \mathrm{mL}^{-1}$ are used in various dye decolorizing experiments [16,17]. Therefore methods to decrease the enzyme loading and reduce the cost of mediators should be further examined [18]. 
In this study natural mediators such as syringaldehyde and acetosyringone were studied with relatively low enzyme loadings ( $300 \mathrm{U} \mathrm{L}^{-1}$ ) with a view to developing a low cost and sustainable laccase-mediator system. The use of laccase with natural phenolic mediators such as syringaldehyde and acetosyringone in a microbial fuel cell for dye decolorization has not been reported so far.

\section{Materials and Methods}

\subsection{Chemicals}

A crude commercial fungal laccase from Trametes versicolor with $10 \mathrm{U} \mathrm{mg}^{-1}$ of activity obtained from Enzyme India Pvt. Ltd., Chennai, India, was used. ABTS, syringaldehyde and acetosyringone were purchased from Sigma Aldrich, Cambridge, UK.

\subsection{Operation of the Microbial Fuel Cell}

An H-type MFC with a working volume of $200 \mathrm{~mL}$ in each chamber was used. Electrodes were made of non-woven carbon fiber, each with a surface area of $25 \mathrm{~cm}^{2}$. Cation exchange membrane CMI7000 ion exchange membrane (Membranes International, Ringwood, NJ, USA) was soaked in 5\% $\mathrm{NaCl}$ for $12 \mathrm{~h}$ before use. External resistance was $2000 \Omega$. This resistance was used because previous studies in our lab had found this to be the optimum for power production using the H-type reactor systems in our laboratory [19].

\subsubsection{Anode Chamber Composition}

The composition in the anode chamber was the same for all reactors. The anolyte consisted of minimal salts medium containing (per liter): $0.46 \mathrm{~g} \mathrm{NH}_{4} \mathrm{Cl}, 0.22 \mathrm{~g}(\mathrm{NH})_{2} \mathrm{SO}_{4}, 0.117 \mathrm{~g} \mathrm{MgSO}_{4}$, $7.7 \mathrm{~g} \mathrm{Na}_{2} \mathrm{HPO}_{4} .7 \mathrm{H}_{2} \mathrm{O}, 2.87 \mathrm{~g} \mathrm{NaH}_{2} \mathrm{PO}_{4}$ along with $1 \%(v / v)$ trace minerals as described by Marsili et al. and $1 \%(v / v)$ vitamin mix as described by Wolin et al. $[20,21]$. The anolyte was supplemented with pyruvate as a carbon source at a concentration of $1 \mathrm{~g} \mathrm{~L}^{-1}$ and casein hydrolysate was also added at $500 \mathrm{mg} \mathrm{L}^{-1}$. The $\mathrm{pH}$ of the anolyte was initially adjusted to 7 . The anode was inoculated with $10 \%$ $v / v$ Shewanella oneidensis MR-1 culture previously grown in Luria Bertani broth to an optical density of 0.4 . The anode chamber was sparged for $10 \mathrm{~min}$ with nitrogen gas to remove any dissolved oxygen and to maintain an anaerobic environment.

\subsubsection{Cathode Chamber Composition}

The cathode chamber consisted of the commercial laccase from Trametes versicolor in $100 \mathrm{mM}$ sodium acetate buffer solution $(\mathrm{pH}=4.5)$ in the presence and absence of redox mediators. Laccase enzyme $\left(300 \mathrm{U} \mathrm{L}^{-1}\right)$ was freely suspended in $200 \mathrm{~mL}$ of $100 \mathrm{mM}$ acetate buffer $(\mathrm{pH}=4.5)$ and $100 \mathrm{mg} \mathrm{L}^{-1}$ of Acid Orange 7 dye was added. After subsequent trial experiments, the concentration of the mediators were set at $50 \mu \mathrm{M}$. The cathode chamber was supplied with air through an air stone at a rate of $200 \mathrm{~mL} \mathrm{~min}^{-1}$.

\subsection{Experimental Design}

Seven MFC systems were set up. System 1 was with S. oneidensis in the anode and laccase enzyme suspended in the cathode chamber in absence of mediators. This system is henceforth referred to as "Control Lac". System 2 was with S. oneidensis in the anode and laccase in the presence of ABTS in the cathode, hereafter referred to as "ABTS-lac". System 3 was with S. oneidensis in the anode and laccase in the presence of syringaldehyde in the cathode, hereafter referred to as "Syr-lac". System 4 was with $S$. oneidensis in the anode and laccase in the presence of acetosyringone in the cathode, hereafter referred to as "As-lac". System 5 was with S. oneidensis in the anode and syringaldehyde in the cathode without laccase, hereafter referred to as "Syringaldehyde". System 6 was with S. oneidensis in the anode and acetosyringone in cathode without laccase, hereafter to as "Acetosyringone". System 
7 was with S. oneidensis in the anode and ABTS in the cathode without laccase, hereafter to as "ABTS". Experiments were conducted at a temperature of $30^{\circ} \mathrm{C}$.

\subsection{Analytical Procedures}

\subsubsection{Acid Orange 7 Decolorization}

The decolorization of $\mathrm{AO} 7$ at the cathode was measured at various time intervals using a UV-visible spectrophotometer at a wavelength of $484 \mathrm{~nm}$, which is the maximum absorption wavelength for the dye. The decolorization efficiency (DE) was calculated by

$$
\mathrm{DE}(\%)=\frac{\mathrm{Ao}-\mathrm{A}_{\mathrm{t}}}{\mathrm{Ao}} \times 100
$$

$\mathrm{A}_{\mathrm{O}}$ and $\mathrm{A}_{t}$ are the absorbance units at the initial and each time point respectively. A time series was plotted for the absorbance values measured.

\subsubsection{Electrochemical Analysis}

The voltage across each MFC system was recorded at 10-min intervals using a Picolog data acquisition system (Pico Technology, St Neots, UK). The current through each system was calculated using Ohm's Law:

$$
\text { Current }(I)=\frac{\text { Voltage }(V)}{\text { Resistance }(\Omega)}
$$

The power produced was calculated using the following formula:

$$
P=I V
$$

where $P$ is power in Watts, $I$ is current in amperes and $V$ is the electric potential in volts.

The power and current per surface area of anode electrode was used to calculate the power and current density. To carry out polarisation tests, each MFC unit was connected to various external resistances ranging from $10 \Omega$ to $1 \mathrm{M} \Omega$, and the steady state potential was measured using a multimeter.

\subsubsection{Cyclic Voltammetry (CV) of Redox Mediators}

The redox activity of the mediators ABTS, syringaldehyde, and acetosyringone in the presence and absence of laccase was analysed using cyclic voltammetry. A three-electrode system with the working electrode as glassy carbon, platinum as the counter, and $\mathrm{Ag} / \mathrm{AgCl}$ as reference electrode was used. The three mediators were each added to $100 \mathrm{mM}$ acetate buffer $(\mathrm{pH} 4.5)$ containing $0.3 \mathrm{U} \mathrm{mL}^{-1}$ laccase to give a final concentration of $50 \mu \mathrm{M}$. CV was carried out using a $\mathrm{CH} 660 \mathrm{~A}$ potentiostat $(\mathrm{CH}$ Instruments) by cycling the potential between $-1 \mathrm{~V}$ to $1 \mathrm{~V}$ at $50 \mathrm{mV} \mathrm{s}^{-1}$.

\subsubsection{Chronoamperometry (CA) of Laccase-Mediators}

The effect of redox activity on current output was measured by CA. The same three-electrode system as used in Section 2.4.3 above was used. The working electrode was poised at $0.7 \mathrm{~V}$, and laccase at a concentration of $0.3 \mathrm{U} \mathrm{mL}^{-1}$ was added to the $50 \mu \mathrm{M}$ mediator solution to observe the change in current. CA was carried out using a CH 660A potentiostat (CH Instruments, Austin, TX, USA).

\subsubsection{Statistical Analysis}

All experimental data indicated in the text and graphs are the means of triplicate experiments unless otherwise stated. The error bars in the graphs and error values in the text represent standard deviations of the mean (SD). Data was analyzed using Microsoft Excel. 


\section{Results and Discussion}

\subsection{Power Generation}

The power density was highest for the ABTS-lac system $\left(77.2 \pm 4.2 \mathrm{~mW} \mathrm{~m}^{-2}\right)$ compared to the control lac system (no mediators), which gave $54.7 \pm 3.5 \mathrm{~mW} \mathrm{~m}^{-2}$ (Figure 2a). The power density of the ABTS-lac system is comparable to the performance of MFCs with platinum-coated cathodes $\left(80 \mathrm{~mW} \mathrm{~m}^{-2}\right)$ obtained in a separate study in our laboratory [data submitted elsewhere for publication]. Similar trends were also obtained by Luo et al., when MFCs with laccase immobilized with Nafion-ABTS produced power $\left(160 \mathrm{~mW} \mathrm{~m}^{-2}\right)$ equivalent to platinum-coated electrodes [1]. The power density in our study was much higher than Schaetzle et al., who obtained $37 \mathrm{~mW} \mathrm{~m}^{-2}$ with laccase-ABTS at the cathode of a MFC [22].

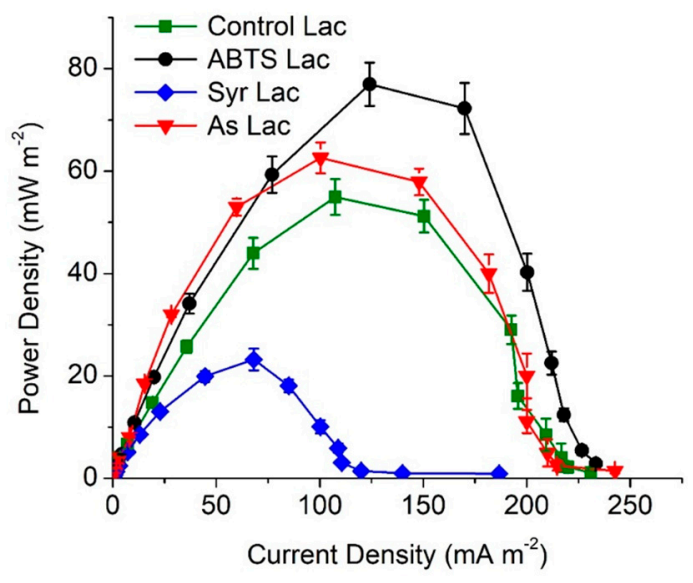

(a)

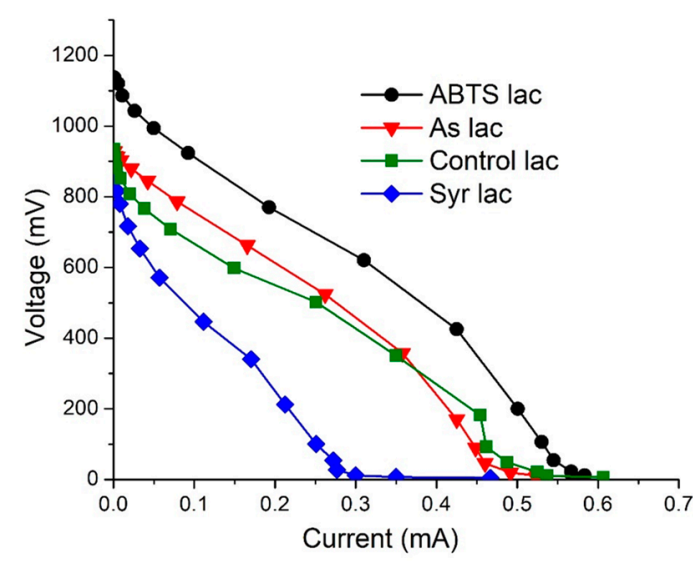

(b)

Figure 2. (a) Power density curves for mediator based laccase cathodes and control MFCs obtained by varying the external resistance from $10 \Omega-1 \mathrm{M} \Omega$; (b) Voltage vs. Current plot.

ABTS is oxidised by laccase, and it can be regenerated (reduced) by receiving electrons from the electrode and/or the dye [23]. The redox potential of the intermediates, $\mathrm{ABTS}^{+}$is $0.68 \mathrm{~V}$ and $\mathrm{ABTS}^{2+}$ is $1.09 \mathrm{~V}$ vs. SHE respectively [6]. The high redox potential of these ABTS radicals aids laccase in efficient reduction of oxygen which occurs at a potential of $1.2 \mathrm{~V}$ vs. SHE.

The As-lac system produced a $P_{\max }$ of $62.5 \pm 3.7 \mathrm{~mW} \mathrm{~m}^{-2}$, and for the Syr-lac system, it was $23.2 \pm 2.1 \mathrm{~mW} \mathrm{~m}^{-2}$ (Figure $2 \mathrm{a}$ ). The power density was higher for the As-lac than the control Lac system and vice versa for the Syr-lac system. The low power produced by the Syr-lac system is probably due to syringaldehyde acting as a substrate for laccase rather than a mediator. Electron donating groups of the benzene ring in phenolic compounds lowers their redox potentials which enables laccase to readily oxidize these substrates, the electrons released being used to reduce oxygen to water [12]. Since phenols are natural substrates for laccase, they are likely to be the source of electrons for oxidation rather than the cathode. This would reduce the power output of MFCs. The higher power density in the control lac systems indicates that in the absence of substrate oxidation, electrons are accepted from the cathode. Although acetosyringone is also a phenolic compound, the power density from the As-Lac system was greater than the control lac system, suggesting that the mediator could have been more efficiently regenerated compared to syringaldehyde. The detailed mechanism for the mediation is discussed in Section 3.3. Thus, from the power density data alone, it can be suggested that acetosyringone is a lower affinity substrate for laccase compared to syringaldehyde. This study is the first use of phenolic mediators in a MFC for laccase oxidation.

The internal resistance for the As-lac system was $1.5 \mathrm{k} \Omega$ compared to $1.8 \mathrm{k} \Omega$ for the control lac system; the ABTS-lac system had an internal resistance of $1.9 \mathrm{k} \Omega$, while Syr-lac system had the highest resistance of $2.2 \mathrm{k} \Omega$ (Figure $2 \mathrm{~b}$ ). 
In the absence of laccase, the power density for cathodes containing syringaldehyde and acetosyringone was $8.6 \mathrm{~mW} \mathrm{~m}^{-2}$ and $7.5 \mathrm{~mW} \mathrm{~m}^{-2}$ respectively.

\subsection{Acid Orange 7 Decolorization}

The decolorization rate of AO7 was highest in case of the As-lac system, followed by the Syr-lac system, and finally, the unmediated laccase biocathode (Figure 3). There was $94 \%$ decolorization in the As-lac system within $24 \mathrm{~h}$ of addition of dye. Decolorization in the control lac system was slightly slower with less than $80 \%$ decolorization in $24 \mathrm{~h}$ (Figure 3). Overall there was $>95 \%$ decolorization for all laccase-based systems after 4 days which was not statistically significant compared to the control. Similar observations were observed for acetosyringone with Reactive Blue dye where $>80 \%$ decolorization was observed in $2 \mathrm{~h}$ under non-MFC conditions [13]. As the two mediators are phenolic compounds that are substrates for laccase they are rapidly oxidized by the enzyme to produce phenoxy radicals that aid in dye decolorization [13]. In the presence of AO7 dye, the mediated laccase prefers the oxidation of dye for electrons rather than the anodic electron source with redox potentials of ca. $-0.2 \mathrm{~V}$ vs. SHE [21]. The mediators are regenerated by abstraction of $\mathrm{H}^{+}$from the dye and $\mathrm{e}^{-}$from the cathode. Syringaldehyde and acetosyringone have been reported to have redox potentials of $0.660 \mathrm{~V}$ and $0.580 \mathrm{~V}$ vs. SHE respectively [24,25]. In the absence of laccase, the mediators have lower redox potential than AO7 (0.693 V vs. SHE); therefore, no decolorization was observed (Figure 3).

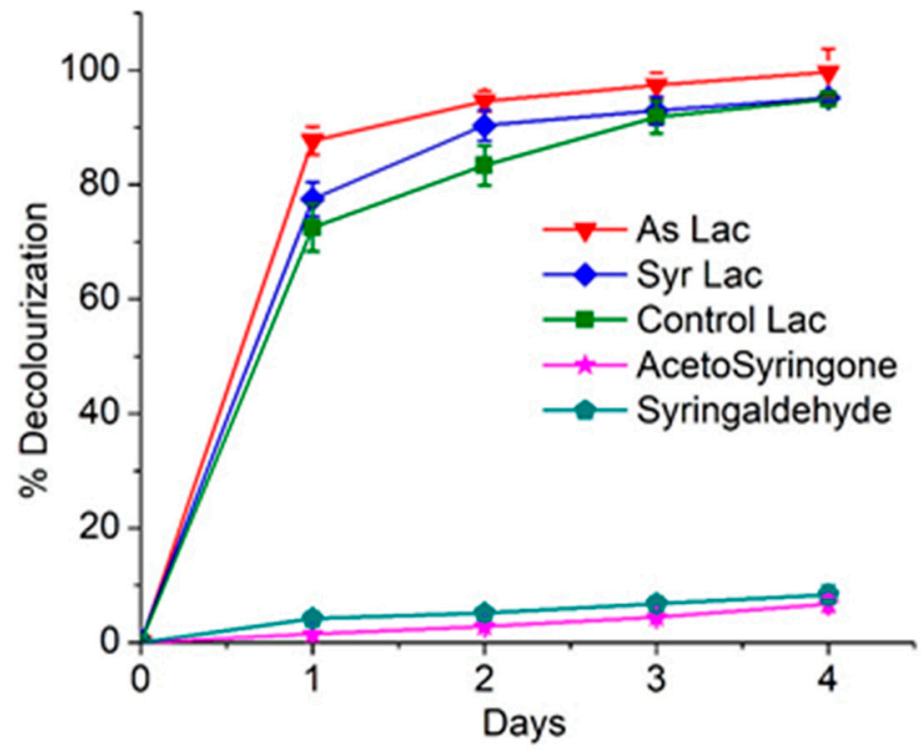

Figure 3. Decolorization of AO7 dye by laccase in the presence and absence of mediators over a period of 4 days.

Decolorization using the ABTS-Laccase system was also attempted for comparison but due to heavy interference with the color of ABTS in the presence of laccase (blue), the decolorization could not be studied effectively.

\subsection{Electrochemical Activity of the Laccase Mediator Systems}

To understand the reaction mechanism of the laccase-mediator systems, cyclic voltammetry was performed. The CV of the Syr system revealed a very weak oxidation peak at $0.73 \mathrm{~V}$ without any quantifiable cathodic current (Figure 4). In presence of laccase the oxidation peak was further decreased indicating syringadehyde's reduction reaction with the enzyme. There was absence of any redox peaks that are characteristic of redox mediators being regenerated. This might be due to laccase oxidizing syringaldehyde to syringic acid while producing phenoxy radicals and syringic acid further oxidizing to 2,6-dimethoxy-1,4-benzoquinone (DMBQ) [26,27] (Figure 5). Due to the subsequent oxidation of 
syringaldehyde, it is not regenerated and available as a mediator. Laccase is capable of catalyzing oxidative polymerization of quinone compounds to form polyhydroquinones [28].

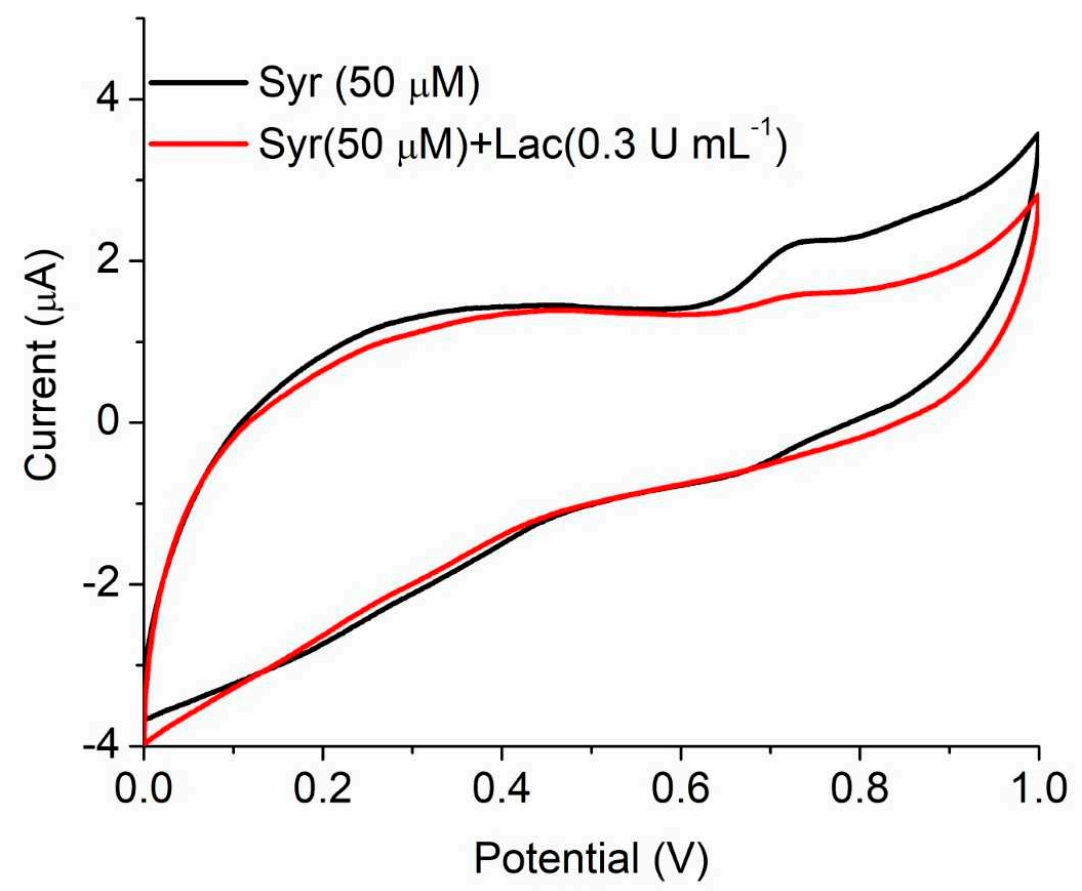

Figure 4. Cyclic voltammetry of syringaldehyde in the presence and absence of laccase at a scan rate of $50 \mathrm{mV} \mathrm{s}^{-1}$. The potential indicated is vs. $\mathrm{Ag} / \mathrm{AgCl}$.

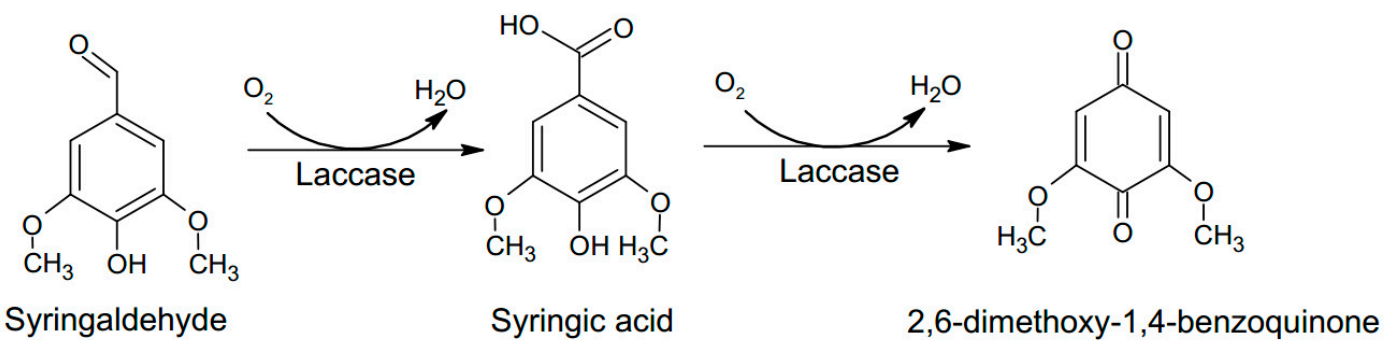

Figure 5. Laccase oxidation of syringaldehyde to syringic acid and subsequent oxidation to benzoquinones [29].

Therefore, the polymerization products of benzoquinone (DMBQ) formed could result in development of concentration gradients and mass transfer limitation at the electrode decreasing the power density. Another possible reason might be a result of the products inhibiting laccase enzyme activity. The CV of acetosyringone produced two redox couple peaks at $0.7 \mathrm{~V} / 0.62 \mathrm{~V}$ and at 0.42 $\mathrm{V} / 0.34 \mathrm{~V}$ (Figure 6). Acetosyringone has two major sites for oxidation/reduction reactions: a hydroxyl group at para position, and a keto group attached to the ring (Figure 7). The redox reactions at these two functional groups contribute to the redox couples in the CV. The functional groups are oxidized to form either a phenoxy radical or an enolate ion. These ions are intermediates of the oxidation reduction reaction stabilized by the aromatic ring. In presence of laccase, the peak at $0.7 \mathrm{~V}$ (close to laccase redox potential $(0.780 \mathrm{~V}))$ was reduced, whereas the cathodic current at the second redox peak was increased and shifted to $0.31 \mathrm{~V}$. This indicates that one of the functional sites is preferably oxidized by laccase. 


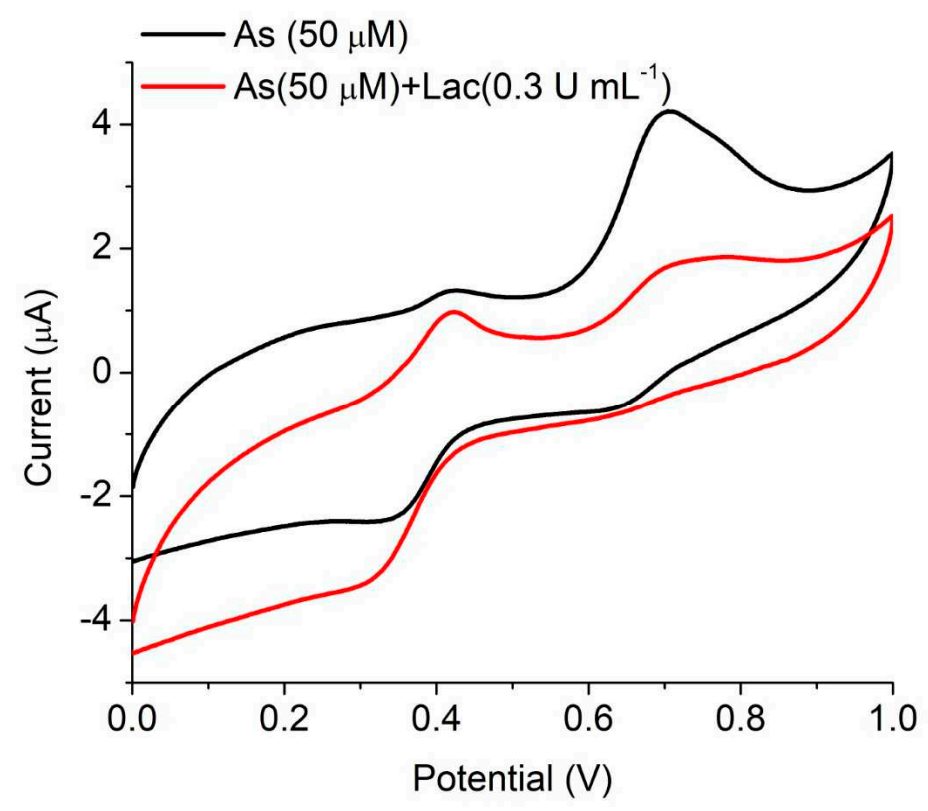

Figure 6. $\mathrm{CV}$ of acetosyringone indicating the oxidation/reduction peak in the presence and absence of laccase at a scan rate of $50 \mathrm{mV} \mathrm{s}^{-1}$.

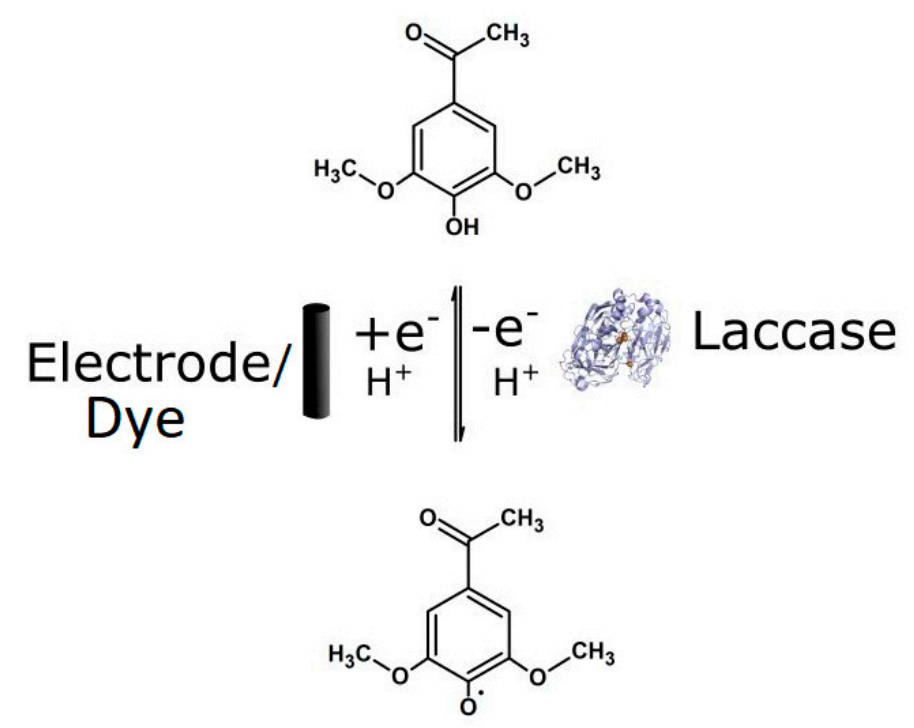

Figure 7. Electron transfer (ET) and Hydrogen atom transfer (HAT) oxidation mechanisms of acetosyringone mediated by laccase.

The two methods of mediation are the Electron transfer (ET) route and radical hydrogen atom transfer (HAT). In the ET route of mediation, only electrons are involved in the formation of free radicals and in the oxidation/reduction of the mediator. In the HAT mechanism, besides an electron, a $\mathrm{H}^{+}$ion is abstracted from hydroxyl groups of the mediators resulting in $\mathrm{O}$ free radical that aids in the mediation. From previous studies, it has been suggested that electron/hydrogen atom abstraction proceeds through the hydroxyl group present on the aromatic ring in acetosyringone [30]. Due to the presence of two functional groups, the mechanism of redox mediation in acetosyringone is a combination of HAT and ET route [26] (Figure 7). The presence of a keto group (as opposed to only hydroxyl) prevents laccase from completely oxidizing the substrate to a different product as observed in syringaldehyde. The acetosyringone is regenerated at the electrode/dye and is available as a mediator, contributing to the higher current output. 
Energies 2018, 11, 3455

9 of 12

In case of ABTS, there were two redo couples: the first at $0.9 \mathrm{~V} / 0.67 \mathrm{~V}$, and the second at 0.63 $\mathrm{V} / 0.45 \mathrm{~V}$ (Figure 8 ). The regeneration (reduction) of ABTS by accepting electrons from the electrode can be observed through increased cathodic current at $0.45 \mathrm{~V}$ in the presence of lactase. ABTS oxidation is a two-step mechanism where first it is oxidized to generate a cationic radical $\left(\mathrm{ABTS}^{+}\right)$that is sequentially oxidized to a di-cation ABS $^{2+}$ (Figure 9) [31]. Hence, a clear decrease in both the oxidation peaks can be observed in the presence of lactase. ABTS is readily oxidized by laccase, and the mediator is constantly regenerated by accepting electrons from the electrode and the dye. The mechanism of ABTS mediation is through the electron transfer (ET) route between the enzyme and the substrate (Figure 9).

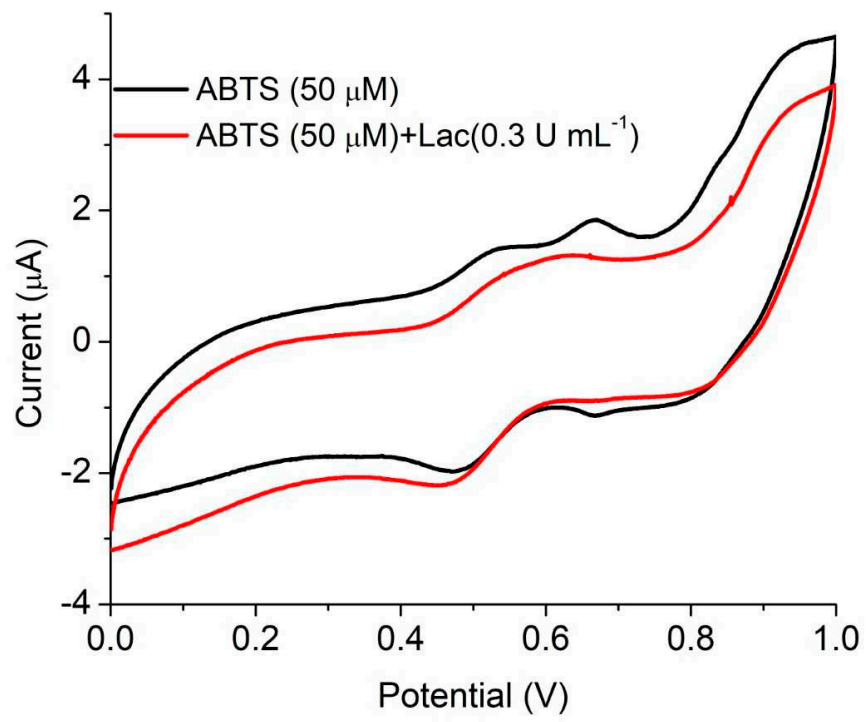

Figure 8. CV of ABTS indicating the oxidation/reduction peak in the presence and absence of lactase at a scan rate of $50 \mathrm{mV} \mathrm{s}^{-1}$.
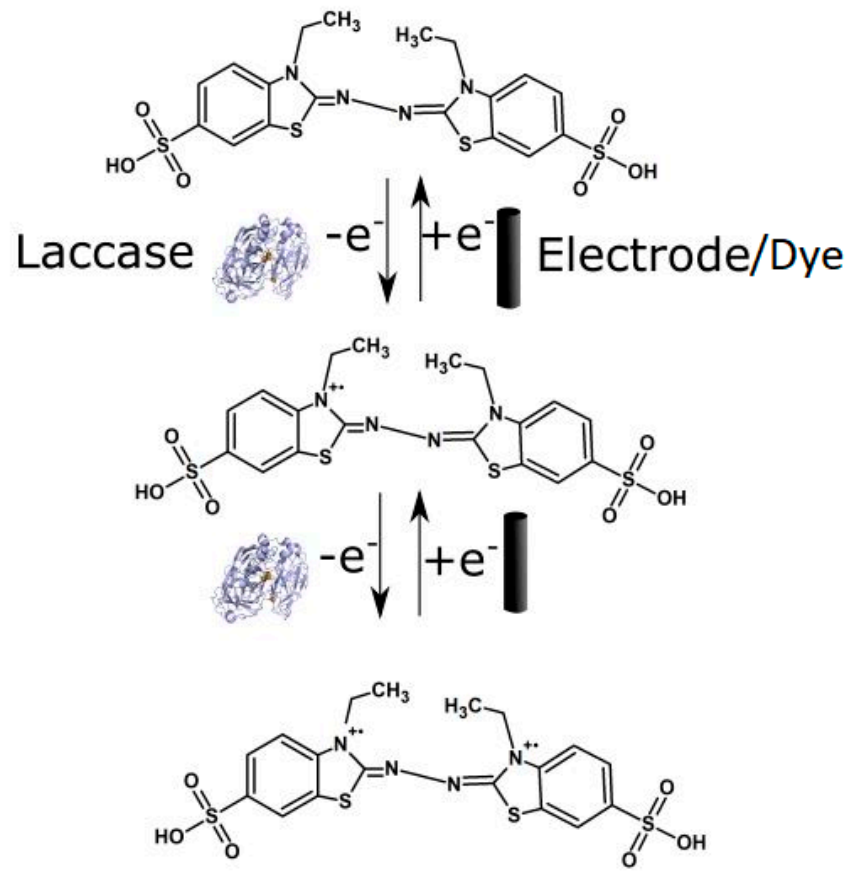

Figure 9. Two step oxidation/reduction of ABTS by lactase and electrode/dye respectively. 
The effect of a laccase-mediator reaction on the current output was further tested by chronoamperometry. It was observed that ABTS system gave the highest cathodic current of $600 \mu \mathrm{A}$, whereas the syringaldehyde and acetosyringone systems produced 150 and $125 \mu \mathrm{A}$ respectively (Figure 10).

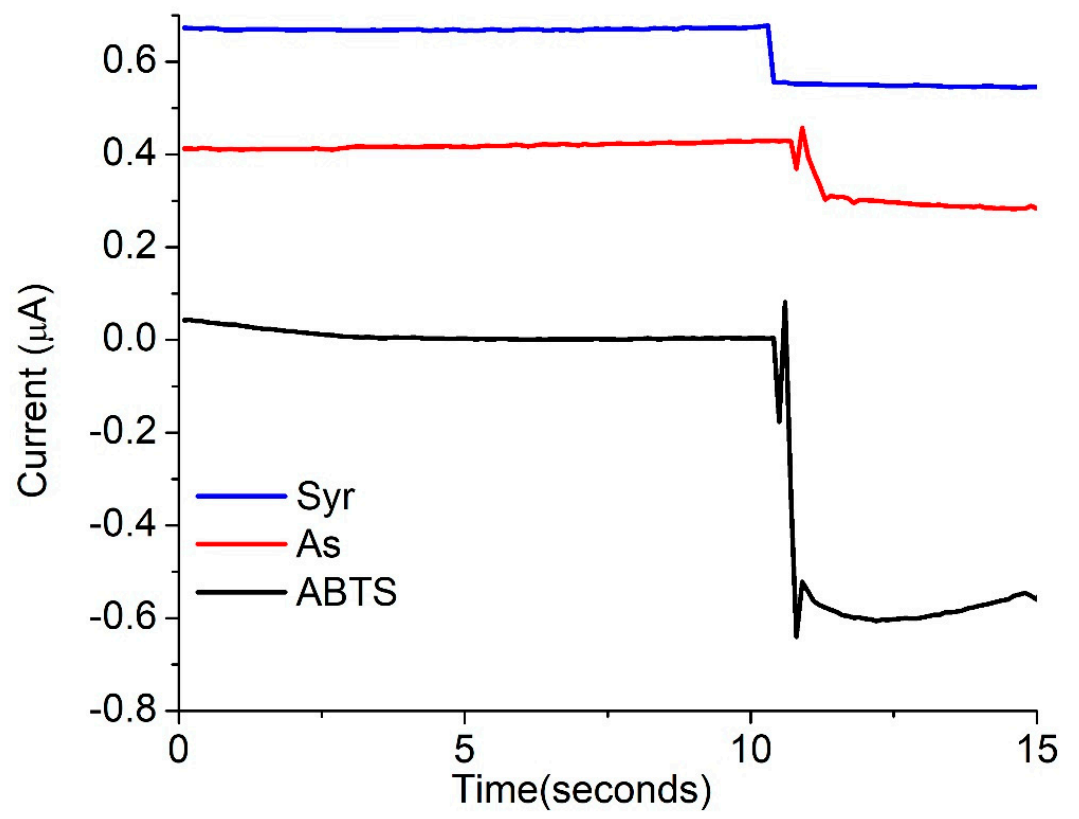

Figure 10. Chronoamperometry depicting the reduction current for each mediator at a concentration of $50 \mu \mathrm{M}$.

Although ABTS was the best mediator in terms of power production, acetosyringone performed comparably with an added advantage of dye decolorization. It is much cheaper and sustainable than ABTS. Syringaldehyde was the best substrate for laccase, and was completely oxidized; thus it did not act as a mediator to improve the performance of the MFC. Overall, the acetosyringone-lac system is preferred for dye decolorization and power production in a MFC.

\section{Conclusions}

Mediators could be used to improve the power density and efficiency of dye decolorization when used with laccase in the cathode of a MFC. For environmental and economic reasons, natural redox mediators such as syringaldehyde and acetosyringone are preferable, and in this study, their effectiveness was compared to those of a commonly used synthetic mediator ABTS. The presence of mediators increased the power density: the ABTS-lac system produced a $P_{\max }$ of $77.2 \pm 4.2 \mathrm{~mW} \mathrm{~m}^{-2}$ while the As-lac system gave $62.5 \pm 3.7 \mathrm{~mW} \mathrm{~m}^{-2}$. The control lac system produced $54.7 \pm 3.5 \mathrm{~mW} \mathrm{~m}^{-2}$ while the power density was the lowest for the Syr-lac system $\left(23.2 \pm 2.1 \mathrm{~mW} \mathrm{~m}^{-2}\right.$.) There was a $16 \%$ increase in decolorization efficiency with addition of mediators as compared to laccase in absence of mediators with As-lac achieving 94\% decolorization in $24 \mathrm{~h}$. The color of ABTS interfered with attempts to quantify the decolorization efficiency of the dye due to ABTS mediation and this is a limitation of this study. Electrochemical analysis performed to determine the redox properties of the mediators, revealed syringaldehyde did not produce any redox peaks, suggesting that it was oxidized by laccase to other products, making it unavailable as a mediator, while acetosyringone and ABTS revealed two redox couples demonstrating the redox behavior of these compounds. Thus, acetosyringone served as an efficient mediator for laccase, aiding in increased rate of dye decolorization and power production in a MFC. 
Author Contributions: P.M. did most of the laboratory work and wrote the initial draft of the paper. G.K., T.K. and T.S.C. helped with the experimental design and review of progress from time to time. V.T.F.K. helped with electrochemical analyses. G.K. edited the paper prior to submission. All authors contributed to proof-reading the paper.

Acknowledgments: Priya wishes to thank her family for sponsoring her Ph.D. studies.

Conflicts of Interest: The authors declare no conflict of interest.

\section{References}

1. Luo, H.; Jin, S.; Fallgren, P.H.; Park, H.J.; Johnson, P.A. A Novel Laccase-Catalyzed Cathode for Microbial Fuel Cells. Chem. Eng. J. 2010, 165, 524-528. [CrossRef]

2. Savizi, I.S.P.; Kariminia, H.R.; Bakhshian, S. Simultaneous Decolorization and Bioelectricity Generation in a Dual Chamber Microbial Fuel Cell Using Electropolymerized-Enzymatic Cathode. Environ. Sci. Technol. 2012, 46, 6584-6593. [CrossRef] [PubMed]

3. Galhaup, C.; Haltrich, D. Enhanced Formation of Laccase Activity by the White-Rot Fungus Trametes Pubescens in the Presence of Copper. Appl. Microbiol. Biotechnol. 2001, 56, 225-232. [CrossRef] [PubMed]

4. Alneyadi, A.H.; Rauf, M.A.; Ashraf, S.S. Oxidoreductases for the remediation of organic pollutants in water-A critical review. Crit. Rev. Biotechnol. 2018, 38, 971-988. [CrossRef] [PubMed]

5. Morozova, O.V.; Shumakovich, G.P.; Shleev, S.V.; Yaropolov, Y.I. Laccase-Mediator systems and their Applications: A Review. Appl. Biochem. Microbiol. 2007, 43, 523-535. [CrossRef]

6. Christopher, L.P.; Yao, B.; Ji, Y. Lignin Biodegradation with Laccase-Mediator Systems. Front. Energy Res. 2014, 2, 12. [CrossRef]

7. Kunamneni, A.; Ballesteros, A.; Plou, F.J.; Alcalde, M. Fungal Laccase-A Versatile Enzyme for Biotechnological Applications. In Communicating Current Research and Educational Topics and Trends in Applied Microbiology; Mendez-Vilas, A., Ed.; FORMATEX: Badajoz, Spain, 2007; pp. 233-245. ISBN 978-84-611-9422-3.

8. Bourbonnais, R.; Paice, M.G. Oxidation of Non-Phenolic Substrates. FEBS Lett. 1990, 267, 99-102. [CrossRef]

9. Call, H.P.; Mücke, I. History, Overview and Application of Mediated Lignolytic Systems, Especially Lacasse-Mediator-Systems (Lignozyme ${ }^{\circledR}$-Process). J. Biotechnol. 1997, 53, 163-202. [CrossRef]

10. Wu, Y.; Teng, Y.; Li, Z.; Liao, X.; Luo, Y. Potential Role of Polycyclic Aromatic Hydrocarbons (PAHs) Oxidation by Fungal Laccase in the Remediation of an Aged Contaminated Soil. Soil Biol. Biochem. 2008, 40, 789-796. [CrossRef]

11. Zeng, S.; Qin, X.; Xia, L. Degradation of the Herbicide Isoproturon by Laccase-Mediator Systems. Biochem. Eng. J. 2017, 119, 92-100. [CrossRef]

12. Cañas, A.I.; Camarero, S. Laccases and Their Natural Mediators: Biotechnological Tools for Sustainable Eco-Friendly Processes. Biotechnol. Adv. 2010, 28, 694-705. [CrossRef] [PubMed]

13. Camarero, S.; Ibarra, D.; Martinez, M.J.; Martinez, A.T. Lignin-Derived Compounds as Efficient Laccase Mediators for Decolorization of Different Types of Recalcitrant Dyes. Appl. Environ. Microbiol. 2005, 71, 1775-1784. [CrossRef] [PubMed]

14. Hilgers, R.; Vincken, J.-P.; Gruppen, H.; Kabel, M.A. Laccase/Mediator Systems: Their Reactivity toward Phenolic Lignin Structures. ACS Sustain. Chem. Eng. 2018, 6, 2037-2046. [CrossRef] [PubMed]

15. Kurniawati, S.; Nicell, J.A. Efficacy of Mediators for Enhancing the Laccase-Catalyzed Oxidation of Aqueous Phenol. Enzyme Microb. Technol. 2007, 41, 353-361. [CrossRef]

16. Mendoza, L.; Jonstrup, M.; Hatti-Kaul, R.; Mattiasson, B. Azo Dye Decolorization by a Laccase/Mediator System in a Membrane Reactor: Enzyme and Mediator Reusability. Enzyme Microb. Technol. 2011, 49, 478-484. [CrossRef] [PubMed]

17. Stoilova, I.; Krastanov, A.; Stanchev, V. Properties of Crude Laccase from Trametes versicolor Produced by Solid-Substrate Fermentation. Adv. Biosci. Biotechnol. 2010, 1, 208-215. [CrossRef]

18. Mani, P.; Keshavarz, T.; Chandra, T.S.; Kyazze, G. Decolourisation of Acid orange 7 in a microbial fuel cell with a laccase-based biocathode: Influence of mitigating $\mathrm{pH}$ changes in the cathode chamber. Enzyme Microb. Technol. 2017, 96, 170-176. [CrossRef]

19. Fernando, E. Treatment of Azo Dyes in Industrial Wastewater Using Microbial Fuel Cells. Ph.D. Thesis, University of Westminster, London, UK, 2014. 
20. Wolin, E.A.; Wolin, M.J.; Wolfe, R.S. Formation of Methane by Bacterial Extracts. J. Biol. Chem. 1963, 238, 2882-2886.

21. Marsili, E.; Baron, D.B.; Shikhare, I.D.; Coursolle, D.; Gralnick, J.A.; Bond, D.R. Shewanella Secretes Flavins That Mediate Extracellular Electron Transfer. Proc. Natl. Acad. Sci. USA 2008, 105, 6-11. [CrossRef]

22. Schaetzle, O.; Barrière, F.; Schröder, U. An Improved Microbial Fuel Cell with Laccase as the Oxygen Reduction Catalyst. Energy Environ. Sci. 2009, 2, 96-99. [CrossRef]

23. Le Goff, A.; Holzinger, M.; Cosnier, S. Recent Progress in Oxygen-Reducing Laccase Biocathodes for Enzymatic Biofuel Cells. Cell. Mol. Life Sci. 2015, 72, 941-952. [CrossRef] [PubMed]

24. Pardo, I.; Chanagá, X.; Vicente, A.I.; Alcalde, M.; Camarero, S. New Colorimetric Screening Assays for the Directed Evolution of Fungal Laccases to Improve the Conversion of Plant Biomass. BMC Biotechnol. 2013, 13, 90. [CrossRef] [PubMed]

25. Baker, C.J.; Mock, N.M.; Whitaker, B.D.; Hammond, R.W.; Nemchinov, L.; Roberts, D.P.; Aver'yanov, A.A. Characterization of Apoplast Phenolics: Invitro Oxidation of Acetosyringone Results in a Rapid and Prolonged Increase in the Redox Potential. Physiol. Mol. Plant Pathol. 2014, 86, 57-63. [CrossRef]

26. Lin, H.; Su, J.; Liu, Y.; Yang, L. Catalytic Conversion of Lignocellulosic Biomass to Value-Added Organic Acids in Aqueous Media. In Application of Hydrothermal Reactions to Biomass Conversion. Green Chemistry and Sustainable Technology; Jin, F., Ed.; Springer: Berlin/Heidelberg, Germany, 2014; p. 109.

27. Volkova, N.; Ibrahim, V.; Hatti-Kaul, R. Laccase Catalysed Oxidation of Syringic Acid: Calorimetric Determination of Kinetic Parameters. Enzyme Microb. Technol. 2012, 50, 233-237. [CrossRef] [PubMed]

28. Sun, X.; Bai, R.; Zhang, Y.; Wang, Q.; Fan, X.; Yuan, J.; Cui, L.; Wang, P. Laccase-Catalyzed Oxidative Polymerization of Phenolic Compounds. Appl. Biochem. Biotechnol. 2013, 171, 1673-1680. [CrossRef] [PubMed]

29. Lahtinen, M.; Kruus, K.; Heinonen, P.; Sipilam, J. On the reactions of two fungal laccases differing in their redox potential with lignin model compounds: Products and their rates of formation. J. Agric. Food Chem. 2009, 57, 8357-8365. [CrossRef] [PubMed]

30. Martorana, A.; Sorace, L.; Boer, H.; Vazquez-Duhalt, R.; Basosi, R.; Baratto, M.C. A Spectroscopic Characterization of a Phenolic Natural Mediator in the Laccase Biocatalytic Reaction. J. Mol. Catal. B Enzym. 2013, 97, 203-208. [CrossRef]

31. Bourbonnais, R.; Leech, D.; Paice, M. Electrochemical Analysis of the Interactions of Laccase Mediators with Lignin Model Compounds. Biochim. Biophys. Acta 1998, 1379, 381-390. [CrossRef] 